Тамара Н. Јаневска

Универзитет у Крагујевцу

Филолошко-уметнички факултет

Студент докторских студија
УДК: 070.41:811.163.41'42

https://doi.org/10.18485/uzdanica.2020.17.2.8

Прегледни рад

Примљен: 31. август 2020.

Прихваћен: 11. децембар 2020.

\title{
ЛИНГВИСТИЧКА (САМО)ИЗОЛАЦИЈА: ИДЕОЛОШКИ АСПЕКТИ НОВИНСКОГ ДИСКУРСА
}

$A \bar{u} c \bar{u} p a \kappa \bar{u}:$ У раду је са идеолошког аспекта спроведена лингвистичка анализа два новинска текста посвећена теми (само)изолације као једног од тренутно горућих друштвених проблема. Настојимо да применом методе критичке анализе дискурса укажемо на експлицитно и имплицитно изнете ставове о датој теми на основу расположивог корпуса и да путем истих дођемо до представа које су присутне у друштву. Фокус истраживања јесте на језичким средствима која се користе ради остварења овог циља, попут појмовних метафора, избора лексике, опозицијама на нивоу речи и реченица и слично. Анализа показује да је присутна извесна противречност у мишљењу, будући да у добу општег индивидуализма (само)изолација наилази на неодобравање друштва.

Кључне речи: идеологија, анализа дискурса, новински дискурс, (само)изолација.

\section{УВОД}

Концепт идеологије издваја се као један од кључних појмова путем којих је могуће објаснити међусобну условљеност наших ставова и поступака (Иглтон 1996: 37; Гоутли 2007: 1). Стога је идеологија један од често анализираних појмова у литератури. Николић и Шарчевић (2014: 14) истичу чињеницу да поједини аутори (попут Де Трејсија и Маркса) идеологију одређују као науку о идејама припадника одређеног друштва која обухвата како скуп знања и веровања, тако и духовни живот и мисаони систем заједнице, што ауторке сматрају неутралним виђењем појма. Исто мишљење дели и Фредрик Џејмсон, дефинишући идеологију као „поглед на свет, који се успоставља у једној епохи, класи, у једном друштву” (Николић 2011: 12). Како се тумачење стварности посредством искуства и чула одвија непрестано, јасно је да је идеологизација саставни део човекове природе (Николић, Шарчевић 2014: 14) који утиче на целокупну друштвену праксу (Манојловић 2014: 56; Зечевић 2014: 116; Карић 2014: 227). Њену свепрожимајућу природу нагла- 
шава и Матовић (2014: 169), напомињући да свако доба људске историје, као и дискурс, почива на одређеној идеологији. Идеологију, дакле, схватамо као одређени поглед на свет који проистиче из односа нашег поимања света и постојећих културних модела (Јовановић 2012: 143). Она је, према речима Џејмса Андерхила (2011: 239), попут бактерије која не може да живи ван организма.

Основни објекат науке о идеологијама, према филозофији идеолошког знака Михаила Бахтина, јесте језик, или реч, будући да се језик разуме као идеолошка репрезентација (Николић 2011: 7). Схватање речи као оптималног идеолошког знака проистиче из њене неутралности, односно способности да се њоме изрази ма која идеолошка функција (Исто: 8). Бахтин даље истиче да „где нема знака - тамо нема ни идеологије”, па је тако знаковна природа основна одлика свих идеолошких појава (Исто). Дакле, као комуникационо средство, језик је сам по себи „идеолошки обојен”, будући да се у њему огледа „виђење његових саговорника, у смислу одабира онога што се изговори, цепањем стварности њеним извлачењем из контекста" (Николић, Шарчевић 2014: 14), те се путем језика идеологија и ствара, а затим је он сам рефлектује (Јосијевић 2014: 27-28), при чему се таква динамика схвата као процес узајамне адаптације између језика и идеологије (Андерхил 2011: 168).

Ширењу и усвајању датих идеологија, као и суспензији једних и настајању других, доприносе медији, који представљају „моћну алатку у служби идеологије” и њено „средство” (Николић, Шарчевић 2014: 15-19). Значај медија огледа се у чињеници да представљају „основ масовног комуницирања у савременим друштвима" који доводе до промена у јавној свести и утичу на облике друштвеног понашања (Ристић, Маринковић 2013: 363). О повезаности идеологије и медијског производа, попут новинског текста којег у оквиру овог рада анализирамо, пише Јоксимовић (2013: 316) истичући да на процес моделовања сваког медијског производа утичу разни контексти од којих је идеолошки контекст само један. Из тога следи да репрезентација и одабир онога о чему се пише умногоме зависе од наслеђених идеолошких оквира, као и да они могу допринети стварању нових концепција.

У складу са изнетим становиштем према коме медији, првенствено новински текст, пружају увид у постојеће идеологије, у раду ћемо сагледати ставове везане за појам (само)изолације на примеру новинских чланака са становишта анализе дискурса. Критичка анализа дискурса представља погодан метод анализе за наше истраживање будући да је њен циљ да открије и истражи постојеће идеологије (Гоутли 2007: 3), односно (скривене) везе између моћи, идеологије и језика које се намећу, између осталог, путем медија, као и чињеница да њен предмет јесу „горући друштвени проблеми” (Силашки, Ђуровић, Радић-Бојанић 2009: 61). Корпус чине текстови „Зашто нам 
изолација тешко пада - забрана појачава жељу за слободом”' и „78 корака по кући" 2 , објављени у дневним новинама Политиика. Посебна пажња у овим текстовима биће посвећена јединицама употребљеним зарад репрезентације имплицитно и експлицитно изнетих ставова у вези са датим проблемом.

\section{АНАЛИЗА ОДАБРАНОГ КОРПУСА}

Већ у самом наслову текста „Зашто нам изолација тешко пада - забрана појачава жељу за слободом" присутни су неки од кључних ставова који прожимају целокупан текст. Најпре се на основу употребе упитног прилога зашйо указује на широко распрострањен став о изолацији, односно, не доводи се у питање да ли нам изолација тешко пада, већ се подразумева да то јесте случај. Такође, употреба личне заменице $м и$ у дативу упућује на чињеницу да је у питању проблем са којим се целокупно друштво суочава, уводећи, на тај начин, мотив заједништва чијем се значају аутор често навраћа у тексту. У другом делу наслова, истакнута је опозиција забрана - жеља за слобоgом која представља основ текста, док избор лексике - који је значајан у идеолошком смислу (Манојловић 2014: 59) - конкретно глагола йојачайи, доводи до тумачења жеље за слободом као једног од човекових основних начела које бива додатно изражено („појачано”) онда када је његова реализација онемогућена. Стога наслов сигнализира идеолошки оквир унутар којег се разматра тема (само)изолације.

Текст отпочиње реченицом која у први план ставља слику човека као друштвеног бића: „Чак и најусамљенији људи имају једну или две особе за које су веома везани и са којима им је неопходно да буду у блиском контакту”. Из приложеног примера можемо уочити да се важност живота у заједници нарочито истиче контрастом између делова најусамљенији љуgи - блиски

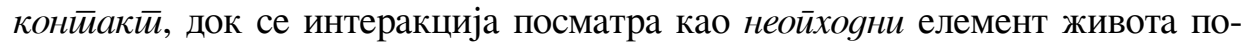
јединца. Међутим, у реченицама које следе такав став доводи се у питање наглашавањем преокрета који је настао развојем технологије и начином живота савременог човека, који се може описати као „брзи ритам живота”. Наиме, социјална интеракција свела се у данашње време на виртуелни вид комуникације: „Разговарамо посредством вајбера. Видимо се преко скајпа. Кратке поруке размењујемо преко месинџера”, што се негативно одразило на човеков живот. То показују статистички подаци у тексту из којих се на имплицитан начин сугерише да је концепција орака и породице нарушена у данашње време, будући да расте број оних који „никада нису стали на луди

\footnotetext{
${ }^{1} \mathrm{http} / /$ www.politika.rs/scc/clanak/4511163ашто-нам-изолација-тешко-пада-забрана-појачава-жељу-за-слободом, 30. 3. 2020.

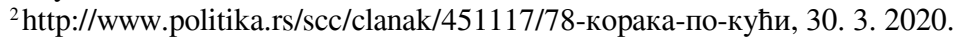


камен” и „не носе бурму”. Усамљеност и самоћа, који су главни резултат измењених друштвених приоритета, приказани су у реченици коју наводимо у изворном облику уз додатну употребу курзива за истицање метафоричких језичких израза који представљају реазлизације присутних појмовних метафора:

Баук усамљености кружи целом планетом - резултати једне америчке студије да се чак 79 одсто припадника Зет генерације, рођене између 1995. и 2010. године осећа усамљено, а са претешким бременом самоће суочава се 71 одсто Миленијалаца и половина „бејби бумера”, рођених после Другог светског рата.

Дакле, у наведеном примеру присутне су две појмовне метафоре првенствено се усамљеност поима као баук, односно „замишљено зло биће којим се плаше деца, страшило” (РСЈ 2011: 64), што доприноси стварању појмовне метафоре УСАМљЕНОСТ ЈЕ ЧУДОВИШТЕ, а затим се самоћа приказује као бреме, па је тако присутна појмовна метафора CAMOЋА JE TEPET. Такво становиште аутор текста поново поткрепљује резултатима студија спроведеним међу припадницима генерације Зет, Миленијалаца и „бејби бумера”. Позивање на поменуте генерације у тексту није случајно, будући да се за њих везују интензивно коришћење технологија, као и одлагање ступања у брак и стварања потомства, што нас поново враћа на идеју измењених идеолошких ставова, на шта нарочито упућује „онтолошко” питање које аутор поставља на крају првог пасуса: „зашто нам тешко пада дистанца и социјална изолација у доба општег индивидуализма?”. Будући да аутор питање поставља на крају пасуса у коме је описан издвојен, самачки начин живљења савременог човека, у питању се перципира извесна доза ироније.

Како би пружио одговор на поменуто питање, аутор се позива на утицајне личности из различитих дисциплина које су се дотакле теме социјалне природе човека. Полази се од књижевности, идеје да је могући одговор понудио Ернест Хемингвеј чији је став био да „Ниједан човек није острво - сам по себи целина. Сваки је човек део континента, део земље [...]”. У примеру је припадност друштвеној заједници представљена на сликовит начин, још једном, путем појмовне метафоре ЧОВЕК ЈЕ МАСА ТЛА НА ЗЕМЉИ, при чему се отуђеност и индивидуалан начин живљења, то јест, човек као индивидуа, поистовећују са острвом. Са друге стране, живот у оквиру колектива приказује се као континент коме човек припада и његов је саставни део. Затим се теми прилази и из аспекта психологије, наводи се мишљење ауторке и професора психологије Гордане Никић која сматра да је потреба да будемо заједно у људској природи. Како би се приказао значај заједништва примењује се појмовна метафора ЗАЈЕДНИШТВО JЕ ОРУЖЈЕ јер у тренуцима „када смо суочени са природним и катастрофама изазваним људском руком” наш инстинкт јесте да „збијемо редове” и изборимо се са недаћама, што асоцира на топлину, сигурност, улива наду и самопоуздање, те је су зајед- 
ништво и припадност групи приказани као пожељни. Ради постизања истог ефекта, употребљава се и метафора ЧОВЕК ЈЕ ЖИВОТИҢА исказана путем термина „психологија крда”. Читаоцима се на тај начин предочава урођеност потребе за блиским односом са сопственом врстом у случају егзистенцијалне угрожености, „јер нас то биолошки смирује”, што се потврђује следећим примером којим се утиче на читаочева осећања: „Сетимо се бомбардовања када смо у склониште ишли са особама које не познајемо и пили кафу чак и са онима са којима нисмо у добрим односима”. У овом примеру манипулативна функција језика долази до изражаја. У чланку се наводе и ставови из области социологије, професора Далибора Петровића који се позива на речи великог грчког филозофа, Аристотела: „човек [je] 'зоон политикон', односно друштвено биће које не може да живи без заједнице". Скрећемо пажњу на употребу негираног модалног глагола моћи којим је истакнута неопходност социјализације, чиме је експлицитно назначено да је таква врста интеракције међу људима обавезна, у истој мери у којој је и природна. Исти је случај са реченицом: „Као људска бића имамо цео репертоар потреба које могу да задовоље само други људи", где употреба искључне речце - само - појачава дати став. Штавише, друштвена страна човека је у нашем колективном несвесном, што се може видети из описа „просечног дана” у човековом животу. Употреба придева йросечан алудира на то да је у питању свакидашњи, ни по чему посебан дан, ипак, у тексту се истиче опречан став - и у таквом дану „имамо много сусрета са људима и минијатурних комуникацијских епизода”, емотивно неутралних контаката, независно од нашег типа личности. Прожимање текста ставовима истакнутих личности и стручњака из различитих сфера живота и дисциплина, попут књижевности, психологије, филозофије и социологије, корисна је стратегија у назначавању важности интеракције међу људима.

Међутим, уследила је промена услед које се сада друштву намећу ставови и видови понашања који су у супротности са човековом природом, јер „пандемија вируса корона [...] као императив успоставља начело - дистанцирајте се да бисте преживели". Дакле, друштву се сада пласирају опречни ставови - уместо блиског контакта са ближњима, дистанцирање од истих

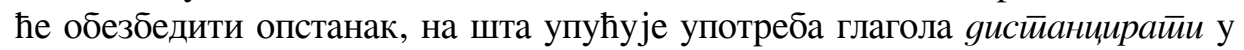
императиву. Такође, глагол йреживейи указује на неопходност поштовања уведених мера, те се читаоцима саопштава да ће у супротном последице бити смртоносне. Контраст овог типа исказан је и у реченици: „Неке од особа које нам највише фале у овом тренутку могу бити смртоносне по нас - за припаднике трећег доба то су деца и унуци". За децу се често везује позитивна конотација, нарочито појам невиности, те се употребом придева смрйоносно контраст наглашава. Штавише, уколико се осврнемо на метафору ВИРУС ЈЕ НЕПРИЈАТЕЉ, која се протеклих пар месеци често употребљава у српској штампи, при чему се борба против вируса поима као рат, произлази став да 
су људи, у нашем примеру деца, (смртоносно) оружје у том рату, будући да су преносиоци вируса.

Не би ли се представило мишљење о самоизолацији у друштву, аутор прави паралелу са давним временима:

Још од античких времена остало је записано да је највећа казна на коју друштво може да нас заштити - социјална изолација, а самица се од установљења пеналног система сматра једном од највећих казни за заробљенике. Сада нас је невидљиви непријатељ у виду вируса осудио на једну од најтежих казни, односно на живот у социјалном карантину.

Уочавамо, дакле, да је вирус метафорички представљен као судија који доноси пресуду у виду социјалног карантина, што доприноси стварању појмовне метафоре ИЗОЛАЦИЈА ЈЕ КАЗНА, те је изолација приказана као непожељна. Ипак, „чињеница је да ми живимо у доба отуђења”, те се у даљем тексту настоји објаснити шта условљава схватање изолације као казне.

Кључни став, и одговор на покренуто питање, исказан је у реченици: „Одлуку да будемо сами или у вези са неким доносимо сами, али сада нам је стављен ембарго на интеракцију, која чини суштину нашег бића". Преноси се мишљење да интеракција са другим људима не мора бити синоним за социјалну блискост, као пример се наводе јапанска домаћинства у којима је изражен мали степен емотивно блиских односа. Према томе, самоћа се доводи у везу са избором, што донекле умањује њен уобичајени негативни дојам. У доба технологије, када смо одабрали да будемо одстрањени, сопственом вољом утонули смо у индивидуализам. Социјална дистанца, са друге стране, јесте ембарїо, одузима могућност одабира, она је „присила” која „фундаментално мења обрасце наше интеракције”. Негативни став имплицира се приказивањем дејства изолације на интровертне особе:

Интровертне особе су до јуче биле задовољне што су водиле социјално аутистични живот и углавном седеле код куће, али то је био њихов избор. Сада им је слобода избора одузета и они имају доживљај да су принуђени да буду у социјалном карантину.

Будући да је за интровертан тип личности уобичајен уздржан однос према другим људима, повлачење из спољашњег света, дакле крајње индивидуалистички карактер, негативни ефекат социјалног карантина бива појачан употребом датог контраста. Овакав начин представљања (само)изолације може навести на закључак да је у питању парадокс - живимо у периоду индивидуализма, ипак изолација нам тешко пада. Анализа текста открива да је у центру пажње, заправо, питање слободе избора. Онда када је социјална дистанца одлука коју доноси сваки појединац, не поима се као штетна. Међутим, њено наметање народу од стране ауторитета схвата се као напад на „суштину нашег бића”, услед чега она доводи до „социјално аутистичног” 
начина живота. Како је сам придев ауйисииччки реч негативне семантике, будући да је његова мотивна реч ауйизам ${ }^{3}$, став друштва о (само)изолацији је више него очигледан. У тексту се износи важна порука: „Ово је моменат [...] да одлучимо да ли желимо да самоћа и изолација буду наш трајни или тренутни избор". На нама је, дакле, да одлучимо да ли ћемо се вратити том одстрањењу након укидања санкција, или се поново повезати са људима.

Други новински чланак који коментаришемо, под насловом „78 корака по кући", илуструје донекле исте ставове о (само)изолацији. У наслову се, као што је то био случај са пређашњим текстом, описује тренутна ситуација на ироничан начин тачним одређењем броја корака које појединац направи у току дана у затвореном простору, што постаје јасно из даљег текста. Конкретно, у примеру: „Уместо по Новом Београду, Весна сада шета 78 корака по стану у којем живи сама", доводе се у везу Нови Београд и стан, при чему се истиче контраст у погледу расположивог простора јер је слобода кретања ограничена на затворени простор, те се читаоцима предочава слика заточеништва.

Почетак чланка посвећује се социјалној природи човека као бића и схватању непосредне интеракције као „преко потребне”, дакле нужне активности. Заправо, употребом негираног модала моћи исказана је немогућност замене блиског контакта технологијом која једино може донекле ублажити терет самоизолације, али не и у потпуности заменити контакт: „непосредна интеракција са другима [...] се не може надоместити технологијом”. У сврху илустрације, у тексту се дејство (само)изолације на појединца описује изразом „изолована душа”, указујући на то да она оставља последице на духовни (мисаони и емотивни) живот појединца. Дакле, делује на читав низ психичких манифестација, те се поима као штетна.

Уводи се мишљење социолога да живимо у доба наглашеног индивидуализма - тврдња која је изнета и у претходном тексту: „Ако погледамо на како трагичан начин се доживљавају превентивне мере остајања код куће, деловаће нам да смо савременици једног изванредног, готово херојског доба индивидуалаца". Значење употребљеног придева йревенйивно указује на то да су мере донесене ради заштите, те се изолација из перспективе струке посматра као позитивна, она је опште добро које осигурава не само здравље, већ опстанак уопште. Стога, опис доживљаја изолације као „трагичне” из позиције народа имплицира да саговорник проблем посматра на ироничан начин, што потврђује и наредна реченица у којој се наводи да тако схваћени трагични доживљај (само)изолације као да надјачава муке оних који су у „заробљеништвима, избеглиштвима, рововима, казаматима, на хладноћи пашњака и врелини њиве”, односно оних који се налазе у правом заточе-

${ }^{3}$ „Повлачење у себе, болесна обузетост сопственом личношћу, неповерљивост према другима, која се јавља обично код шизофреничара" (РСJ 2011: 49). 
ништву. Дато понашање се подругљиво описује приказивањем савременог човека као „Прометеја 21. века”. Асоцијације које настају на помен имена Промейеј јесу храброст, пркос и понос, још важније, човекољубивост и жеља за слободом, будући да је Прометеј за казну био прикован за Кавказ. Као симбол поменутих вредности, уочава се јасан контраст у односу на друштво чији припадници „нису приковани за зидове својих домова због племенитих побуда да учине свет бољим", као што је то био случај са Прометејем. Пример попут овог показује како позивање на личности или појмове који су симбол одређених вредности или се за њих везују одређене идеологије може послужити као један од начина откривања имплицитних ставова о одређеном проблему.

Доминанантност неолибералне идеологије дата је у тексту као неповољан механизам јер распламсава егоизам у друштву: „Таква материјалистичка подлога је погодна за бујање егоцентричних тежњи, које не препознају опште добро, па ни елементарну солидарност, преко потребну у овој ситуацији". Преноси се мишљење да незадовољство које се јавља услед доношења одлуке о изолацији почива на „заборављеном наличју индивидуализма”. Заправо, употребом глагола крийи се којим се аутор служи при објашњењу ове динамике назначено је да су корени тог незадовољства неприметна последица индивидуализма коме смо се окренули. При томе смо заборавили на међузависност људи као бића: „у задовољавању потреба сваког од нас учествују милиони људи широм планете”. На пример, мотив заједништва маркира се употребом опште заменице сви и придевом зајеgничка у реченици: „Повезани међусобном зависношћу, сви делимо и заједничку судбину”. У тексту

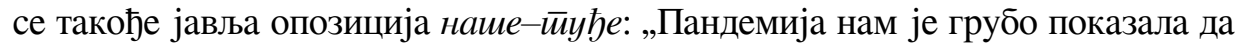
патње једног дела човечанства врло лако могу да постану и наше”, при чему се контрастирају наше, српско друштво и остала друштва и премошћавају се културне и друштвене разлике на које дата опозиција алудира. Исти став преноси се реченицом испуњеном емоционалним елементима којима се намеће слика подељене патње, јер сви припадници друштва теже истом: „постоје и други људи који такође желе брашно, тестенину и пиринач и не желе да се разболе и заразе своје ближње”.

На крају текста истакнута је важност неопходне солидарности и одговорности према себи и другима „јер не зависимо само ми од безброј других људи - и безброј других зависи од сваког од нас". Порука је дата у форми критике због одсуства поменутих вредности које морају надјачати наше „чудне хирове у чудна времена”. 


\section{ЗАКЉУЧАК}

Анализа корпуса открива присуство индивидуализма као владајуће идеологије у друштву који се у текстовима изједначава са субјективизмом, себичношћу и егоизмом. Концепт сам по себи супротставља се колективизму, што је још једна од тема покренутих у текстовима, подразумева, дакле, „издвајање из масе” и „прихватање себе самог као слободне личности која је одговорна за сопствене поступке" (Бошковић 2017: 8).

Негативни став према индивидуализму у текстовима исказан је у самим насловима, где се на ироничан начин описују ставови у друштву у вези са (само)изолацијом који наизглед нису у складу са датом идеологијом, будући да друштво ову меру не прихвата и види је као напад на суштину бића. У текстовима се наглашава слика човека као друштвеног бића позивањем на ставове ауторитета из области књижевности, психологије, социологије и филозофије, чиме се „уноси нота објективности” (Јанић 2014: 76). Истицање значаја колективизма и припадности заједници постиже се употребом опште заменице сви и личне заменице ми, затим честим експлицитним помињањем лексеме зајеgнички, зајеgно и зајеgница, као и опозицијом наше-йуђе. Будући да различите метафоре носе различите идеолошке импликације (Манојловић 2014: 61), у корпусу се јавило и неколико појмовних метафора којима је истакнут мотив заједништва, попут: ЧОВЕК ЈЕ МАСА ТЛА НА ЗЕМЉИ, ЗАЈЕДНИШТВО ЈЕ ОРУЖЈЕ и ЧОВЕК ЈЕ ЖИВОТИҢА. СТАВ који се износи јесте да је блиски контакт једна од природно условљених потреба човека која се не може надокнадити технологијом, што се у тексту често постиже употребом негираног модалног глагола моћи, или искључне речце само при наглашавању међузависности у друштву. (Само)изолација, са друге стране, означена је лексемама ембаріо, йрисила, ауйисииични живой. Такође, представљена је путем појмовне метафоре ИЗОЛАЦИЈА ЈЕ КАЗНА, док су усамљеност и самоћа које изазива обележени појмовним метафорама УСАМЉЕНОСТ ЈЕ ЧУДОВИШТЕ и САМОЋА ЈЕ ТЕРЕТ. Анализа стога показује да су ставови о изолацији у друштву превасходно негативни, при чему се као главни разлог у тексту наводи „одузета” могућност слободе избора, будући да је савремени човек у „доба општег индивидуализма” навикао да сам доноси одлуку да ли ће блиски контакт бити један од приоритета у животу.

\section{ИЗВОРИ}

Димитрије Буквић, „78 корака по кући”, Полийика, 30. 3. 2020, преузето са cajта: http://www.politika.rs/scc/clanak/451117/78-корака-по-кући.

Катарина Ђорђевић, „Зашто нам изолација тешко пада - забрана појачава жељу за слободом”, Политика, 30. 3. 2020, преузето са сајта:_http://www.politika.rs/ 
scc/clanak/4511163ашто-нам-изолација-тешко-пада-забрана-појачава-жељу-за-слободом.

\section{ЛИТЕРАТУРА}

Андерхил (2011): James W. Underhill, Creating Worldviews: Metaphor, Ideology and Language, Edinburgh: Edinburgh University Press Ltd.

Бошковић (2017): Aleksandar Bošković, Individualizam u antropologiji, u: S. Ignjatović, A. Bošković (ur.), Individualizam, Beograd: Institut društvenih nauka, 4-25.

Гоутли (2007): Andrew Goatly, Washing the brain - metaphor and hidden ideology, Amsterdam: John Benjamins Publishing Company.

Зечевић (2014): Снежана Зечевић, Културно-идеолошка моћ језика у рекламним огласима у часописима намењеним женама, у: Д. Бошковић (ур.), Филолоїије vs иgеолоїије, Крагујевац: Филолошко-уметнички факултет, 113-132.

Иглтон (1996): Terry Eagleton, The Illusions of Postmodernism, Oxford: Blackwell Publishing Ltd.

Јанић (2014): Александра Јанић, Употреба енглеских речи у српском језику: Идеолошка перспектива на примеру два новинска чланка, у: Д. Бошковић (ур.), Фuлолоїије vs иgеолоїје, Крагујевац: Филолошко-уметнички факултет, 67-78.

Јовановић (2012): Ана Јовановић, Идеологије образовања и рецепција страних језика, у: М. Ковачевић, Д. Бошковић (ур.), Савремено ярушииво и криза ироучавана језика и књижевностии, Крагујевац: Филолошко-уметнички факултет, 141-154.

Јоксимовић (2013): Zorana Joksimović, Žena kao subjekt novinskog teksta, u: D. Valić Nedeljković, D. Pralica (ur.), Digitalne medijske tehnologije i društveno-obrazovne promene 3, Novi Sad: Filozofski fakultet, 315-328.

Јосијевић (2014): Јелена Јосијевић, Језичка варијација у Дизнијевим анимираним филмовима, у: Д. Бошковић (ур.), Филолойије vs иgеолоїие, Крагујевац: Филолошко-уметнички факултет, 27-42.

Карић (2014): Милица Карић, Идеологија и књижевност: Јержи Косински као обојена птица, у: Д. Бошковић (ур.), Филолоіије vs иgеолоїије, Крагујевац: Филолошко-уметнички факултет, 227-236.

Манојловић (2014): Нина Манојловић, Слика жене у српском друштву спектакла, у: Д. Бошковић (ур.), Филолоїије vs иgеолоїие, Крагујевац: Филолошко-уметнички факултет, 55-66.

Матовић (2014): Тијана Матовић, Идеолошки аспекти романа Преgайор Владимира Арсенијевића, у: Д. Бошковић (ур.), Филолоїије vs иgеолойије, Крагујевац: Филолошко-уметнички факултет, 169-180.

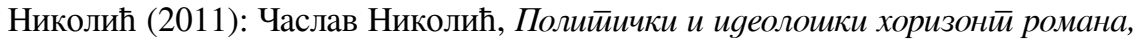
есеја и новинских чланака Милоша Црњанской, Крагујевац: Филолошко-уметнички факултет.

Николић, Шарчевић (2014): Ивана Николић, Ана Шарчевић, Идеологизација Божића у англоамеричком друштву, у: Д. Бошковић (ур.), Филолойuје vs ugeoлоїuје, Крагујевац: Филолошко-уметнички факултет, 13-26.

Ристић, Маринковић (2013): Dušan Ristić, Dušan Marinković, Medijske tehnologije i dekontekstualizacija kognicije: mapiranje tihog glasa ideologije, u: D. Valić Nedeljko- 
vić, D. Pralica (ur.), Digitalne medijske tehnologije i društveno-obrazovne promene 3, Novi Sad: Filozofski fakultet, 361-369.

РCJ (2011): Речник срйскойа језика, Нови Сад: Матица српска.

Силашки, Ђуровић, Радић-Бојанић (2009): Nadežda Silaški, Tatjana Đurović, Biljana Radić-Bojanić, Javni diskurs Srbije: kognitivističko-kritička studija, Beograd: Centar za izdavačku delatnost Ekonomskog fakulteta.

Tamara N. Janevska

University of Kragujevac

Faculty of Philology and Arts

PhD student

\section{SOCIAL DISTANCING: THE IDEOLOGICAL PERSPECTIVE IN JOURNALISTIC DISCOURSE}

Summary: The paper examines the ideological perspective on the topic of social distancing from the aspect of Critical Discourse Analysis. Limiting our analysis to two newspaper articles, we seek to define both the explicitly and implicitly conveyed attitudes about the issue at hand by conducting the linguistic analysis. Special attention is payed to conceptual metaphors, comparisons, various oppositions and other means which contribute to the representation of social distancing present in the society. The analysis pointed to a central paradox, given that in the age of individualism, there is a general unacceptance of social distancing measures.

Key words: ideology, discourse analysis, journalistic discourse, social distancing. 